\title{
特集 /耳鼻咽喉科
}

喉頭腫瘍とレーザー
Laryngeal Tumor and Laser

井上 鐵三，田部 哲也，小倉 雅実

北原 哲, 中之 坊学, 大前由紀雄 防衛医科大学校耳鼻咽喉科

Tetsuzo INOUYE, Tetsuya TANABE, Masami OGURA, Satoshi KITAHARA, Manabu NAKANOBOH and Yukio OHMAE

Department of Otolaryngology, National Defense Medical College

Namiki 3-2, Tokorozawa, Saitama 359

\author{
要 旨 \\ $\mathrm{CO}_{2}$ レーザーあるいはKTP/532レーザーで治療した, 声門癌 T146症例について検討した。 5
} 年確定生存率は100\%であった。喉頭保存率はT 1 a $96 \% ， T １$ b $80 \%$ であった。音声機能は日 常生活上満足できるものが保存された。この結果から，以下の結論を得た。1）前連合の病変はレ 一ザーによる切開蒸散で治療可能である。2）声門癌 T 1 はレーザー手術単独で治療可能である。 キーワード： $\mathrm{CO}_{2}$ レーザー: $\mathrm{KTP} / 532$ レーザー，喉頭腫㾤，声門癌，音声機能

\begin{abstract}
Abstruct
Forty six cases of glottic carcinomas treated with $\mathrm{CO}_{2}$ laser or $\mathrm{KTP} / 532$ laser were reviewed. The 5-year determinate survival rate was $100 \%$. The voice conservation rate was $96 \%$ for $\mathrm{Ta}$ and $80 \%$ for $\mathrm{T} 1 \mathrm{~b}$. Vocal function was satisfactorily preseved for daily life. The results led to the following conclusion: 1) Lesions involving anterior commissure can be treated by laser excision and vaporization. 2) Glottic $\mathrm{T} 1$ carcinomas can be treated by laser surgery alone.
\end{abstract}

Key Wards: $\mathrm{CO}_{2}$ laser, KTP $/ 532$ laser, laryngeal tumor, glottic carcinoma, vocal function

\section{1 . 目的}

約30年前に、レーザーという新しい光が発振されて以 来, この光は精密計測・通信・加工・エネルギー開発な どに広く普及したが，医学分野への応用もまた盛んに行 われてきた。

耳鼻㸶喉科領域においても1972年頃より熱作用による
切開あるいは蒸散能力を利用して, 種々のレーザーが 種々の疾患に用いられてきたが”，なかでも喉頭癌の治 療においては， $\mathrm{CO}_{2}$ レーザーが導入され良好な治療成績 が報告されている2゙3い。今回，現在までに当科で行っ た喉頭癌レーザー治療のうち，声門癌 T 1 症例について 検討したので報告する。 


\section{2. 対象および方法}

対象は，1982年4月から1991年3月の間にレーザー手 術を行った, 声門部喉頭癌 T 1 新鮮例46例（T 1 a 26 例, T 1 b 20(例) である。

治療は，全身麻醉，喉頭顕微鏡下に， $\mathrm{CO}_{2}$ レーザーあ るいはKTP/532レーザーを用いて、腫瘦を蒸散・切除 することによって行った。マイクロマニピュレーターを 通した非接触照射を多く用いたが，KTP－532レーザー ではハンドピースによる接触照射も併用した。

レーザ一照射の条件は, 当初の $2 \sim 3$ 年間は, 出力 5 $\sim 10 \mathrm{Watt} \cdot$ Defocused BeamのPulse照射で，腫瘳を 蒸散することによって治察していたが，その徯は通常10 〜20Watt · Focused BeamのContinuous Wave古る いはSuper Pulse照射を用いて，可及的短時間に病巣を 切除し，必要に応じて残存組織を蒸散するようにした。

レーザー手術後は切除断端より数力所生検を行い，切 除標本上之もに病理組織学的に検討し，腫㿑の残存が疑 われる症例に対しては，繰り返しレーザー手術を追加す るか, 放射線治療の併用を行った。治療成績の判定は，

間接喉頭鏡検查・喉頭ファイバースコピー・喉頭ファイ バースコピー下の生検を中心に行った。

治療後の音声については，18例（T1a 9例, T1b 9 例)に対し，レーザー手術後 1〜4年経過した時点 で, 日本音声言語医学会が定めた声の検査法りに基づい て音声機能検査を奏施し検討した。検査はフォノラリン ゴグラフ(リオン SH－01）を用いて、最長発声持続 時間・楽な発声時 (無関位発声時) の平均呼気流率・無 関位発声時の声の基本周波数・無関位発声時の声の強さ ・声の周波数域 (声域) ・声の強さ域の 6 項目を行い， 合わせてGRBAS尺度による聴覚心理的評洒も行った。

\section{3. 成 績}

T 1 a の26症例に関しては，18例がレーザー手術単独 で1次治療を終了した。残りの8例は，1次治療にレー ザー手術と放射線照射在併用し，うち5例は術㖟照射で， 3 例は術前照射後の残存腫皦に対してレーザー手術を施 行した。術後照射を行った 5 例中 3 例は、レーザー治療 を開始した当初の症例で, 術後病理組織学的に腫㴼消失 之判断したが，予防的に放射線照射を追加した症例で 南った。このように，T 1 a 症例では, 全例喉頭を保存 して1次治療を行い得た。ただし，その後の経過観察で， レーザー手術単独の18例中1例において，5力月後に声 帯の可動性制限を認め, r T 3 と判断し㬋頭摘出を行っ た（表 1 )。

T 1 b の20症例では，10例がレーザー手術棵独で 1 次
表 1, T 1 a症例の治療結果

\begin{tabular}{|c|c|c|c|c|}
\hline & 制御 & 残存 & 再 & 発 \\
\hline レーザー単独 & 18 & 0 & $1 / 18$ & $(6 \%)$ \\
\hline レーザー後放射線 & $5^{*}$ & 0 & $0 / 5$ & $(0 \%)$ \\
\hline 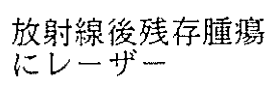 & 3 & 0 & $0 / 3$ & $(0 \%)$ \\
\hline 計 & 26 & 0 & $1 / 26$ & $(4 \%)$ \\
\hline
\end{tabular}

表 2. T 1 b 症例の治療結果

\begin{tabular}{|c|c|c|c|c|}
\hline & 制御 & 残存 & 再 & 発 \\
\hline レーザー旄独 & 10 & 0 & $1 / 10$ & $(10 \%)$ \\
\hline レーザー後放射線 & $5^{*}$ & 0 & $1 / 5$ & $(20 \%)$ \\
\hline 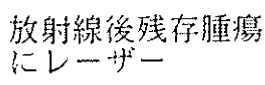 & 3 & 2 & $0 / 3$ & $(0 \%)$ \\
\hline 計 & 18 & 2 & $2 / 18$ & $(11 \%)$ \\
\hline
\end{tabular}

治療を終了した。残りの10例中 5 例は、レーザー手術後 放射線照射で1次治瘖岩終了したが，このうち3例は， レーザー治療を開始した当初の症例で, 術後病理組織学 的に腫瘍消失上判断したが，予防的に照射を追加した症 例であった。他の5例は，術前照射捘の残存腫痬に対し てレーザー手術を施行した症例で，うち３例で腫演は消 失したが，2例では腫湯が残存し喉頭を摘出した。この ように，T1b症例では，20例中18例で喉頭を保存して 1次治療老行い得た。をの後の経過観察においては,レー ザー手術単独の10例中1例で 4 力月後に再発を認め, ま た術後照射䒵行った 5 例中 1 例で 2 年後に再発を認め， 喉頭摘出となった（表 2 )。

全症例について、レーザー治療を開始した前期25症例 (1982 1986) 上. ₹の後の後期21症例（1987 1991） とに分けて，治療成績を比皎检討した（表 3 )。吉ず, 前期の25症例では，8例がレーザー手術单独で1次治療 を終了した。このうち1例でその後再発を珰め, 喉頭摘 出を行った。9例はレーザー手術後放射線照射で 1 次治 瘵を終了したが、このうち 6 例は術後病理組織学的に腫 㩐消失上判断したが，予防的に照射を追加した症例で あった。他の8例は、術前照射㖟の残存腫潝に対してレー ザー手術を施行した症例で，うち６例で腫瘏は消失した が，2例では腫漟が残存し晚頭摘出を行った。つぎに， 後期の 21 症例では，20例がレーザー手術単独で 1 次治療 を終了した。このうち1例でその後再発を認め, 喉頭摘 出を行った。残りの1例はレーザー手術後腫瘍が残存し 
表 3 レーザー治療前期と後期の結果

\begin{tabular}{|c|c|c|c|c|c|c|c|c|}
\hline & \multicolumn{4}{|c|}{ 前期 25 例（1982～1986） } & \multicolumn{4}{|c|}{ 後期21例（1987～1991） } \\
\hline & 制御 & 残存 & 再 & 発 & 制御 & 残存 & 再 & 発 \\
\hline レーザー単独 & 8 & 0 & $1 / 8$ & $(13 \%)$ & 20 & 0 & $1 / 20$ & $(5 \%)$ \\
\hline レーザ一後放射線 & $9^{*}$ & 0 & $1 / 9$ & $(11 \%)$ & 1 & 0 & $0 / 1$ & $(0 \%)$ \\
\hline 放射線後残存腫痬 & 6 & 2 & $0 / 6$ & $(0 \%)$ & 0 & 0 & $0 / 0$ & $(0 \%)$ \\
\hline 計 & 23 & 2 & $2 / 23$ & $(9 \%)$ & 21 & 0 & $1 / 21$ & $(5 \%)$ \\
\hline
\end{tabular}

残存・再発の5例は喉頭摘出

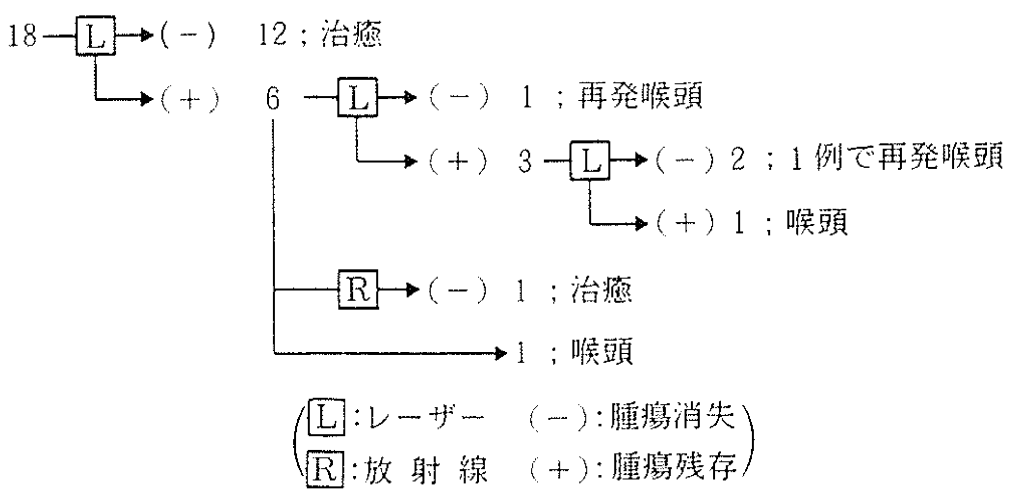

図 1。前連合部腫瘍の治療経過

放射線照射を追加して1次治療を終了した。後期におい ては，T1症例はレーザー手術苑第一選択としたため， 術前照射を行った泟例はなかった。

前期の25例をまとめると，㬋頭を保存して治療できた

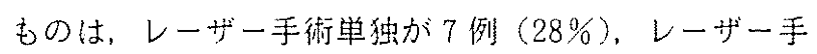
術上放射線照射の併用が14例（56\%）であり，喉頭摘出 を要したものが 4 例（16\%）であった。後期の21例をま とめる上，旺頭を保存して治療できたものは，レーザー 手術単独が19例 $(90 \%)$ ，レーザー手術と照射の仿用が 1 例 (5\%)であり，喉頭摘出を要したものは1例(5 6) であった。

つぎに，T1 b 20症例のうち前連台に腫痿在認めた18 例について橫討した。15例 $(83 \%$ は） 3 回志でのレー ザー手術（1回12例，2回1例，3回2例)で制御され

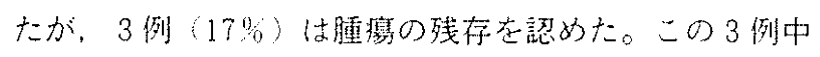
1 例は，放期線治療を行い治療したが，他の2例は㺼頭 摘出在要した。吉た、レーザー手術で腫演消失と判断し た15例のうち2例は後に再発在認めており。これらは レーザー手術を2ないし3回行った症例ですった。以上 18例の前連合部腫演に対する治療経過を図1に示した。 この結果をまとるると，最終的にレーザー手術で制御さ 机たものは、18例中13例(72\%)で，うち12例はレーザー 手術回数1回であった。1回のレーザー手術後に，腄弼
の残存を認めた 6 例のうち、レーザーあるいは照射の追 加で治療できたものは2例であり，他の4例は最終的に 喉頭摘出を琵した。

喉頭保存率については，1次治療においては，46例中 44 例 (96\%) が喉頭を保存して治療学終了していた。こ のうち、 3 例に再発を認め, 鼠終的にはT1の喉頭保存 率は89\%という結果であった。

全症例の経過観察期間は, 1 年 1 力月から9 年11力月 (平均 4 年10力月) であり，死亡例は，T 1 aでの他因 死 1 例のみであった。生存率は, 3 年・5 年確定生存率 よもに100\%,であった。

術㣪の音声機能については，最長発声持続時間の平均 は13sec程度で，正常より短い結果であったが，T 1 a とT 1 bに差を認めなかった。無関位発声時の平均呼気 流率は，正常値を上回っているものが多く，T１ｂでは 特に顕著であった。無関位発声時の声の基本周波数も正 常值より大きく，T1bではT I a より多少大きく，か つ,ばらつく㑯向が見られた。無関位発声時の声の強さ は、T1 a・T 1 bともにほぼ正常範国であった。声域 (声の周波数域) は正常より狭く, 高音低音ともに出し にくく，特に呧い声が出にくい傾问があった。この傾向 はT1りでより強く認められた。声の強さ域は狭く、T laでは特に小さい声が出しにくく，T1bでは小さい 
表 4. 発声機能検查成績

\begin{tabular}{|c|c|c|c|}
\hline & & T1 a 9 例の平均 & $\mathrm{T} 1 \mathrm{~b} 9$ 例の平均 \\
\hline 最長発声持続時間 & $(\mathrm{sec})$ & 13.3 & 13.5 \\
\hline 平均呼気流率 & $(\mathrm{m} / \mathrm{sec})$ & 264 & 339 \\
\hline 基本周波数 & $(\mathrm{Hz})$ & 174 & 185 \\
\hline 音生レベル & $(d B)$ & 86 & 81 \\
\hline \multirow[t]{3}{*}{ 声 域 } & $(\mathrm{Hz})$ & 126 & 156 \\
\hline & 上限 $\quad(\mathrm{Hz})$ & 259 & 268 \\
\hline & 幅 (半音) & 25 & 17 \\
\hline \multirow{3}{*}{ 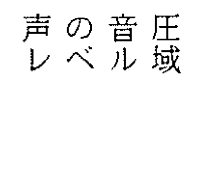 } & 下限 $\quad(d B)$ & 79 & 77 \\
\hline & 上限 $\quad(\mathrm{dB})$ & 95 & 89 \\
\hline & 幅 (dB) & 16 & 12 \\
\hline
\end{tabular}

声大きい声上もに出しにくい傾向が見られた（表４）。 嗄声の聴覚心理的評価は，嗄声のないもの（G0）ある いは軽度のもの（G1）はT 1 a で 5 例（56\%），T1b で 4 例 $(44 \%)$ と大きな差はなかったが，T 1 bでは嗄 声の高度のもの（G 3 ）を2例に認めた。榎声の性質と しては，T1 a，T1bともに気息性因子が最も強く， ついで粗造性因子が強く，努力性因子は T 1 bで 1 例に 認めたのみであり，無力性因子は全例に認めなかった。

以上をまとめると，無関位発声時の基本周波数は正常 より高く，声域は狭くなり，特に低い声が出しにくい傾 向があった。声の強さは，無関位発声時ではほぼ正常で あったが，音圧レベル域の幅が狭く，また声を小さくす ることが難しい傾向であった。嗄声の主なる性質は気息 性嗄声であり，発声持続時間は正常より短かった。

\section{4. 考 察}

喉頭癌治療にCO $\mathrm{CO}_{2} レ$ レ゙ーが用いられ，20年が経過し ようとしているが，最近では，その使用方をexcisional biopsyに限るとする報告が多い3６）》。すなわち，適 応を声門癌 T 1 のうち，腫瘍が声帯膜様部に限局したも の（前連合上声帯染起に腫乑を認めないもの）としてい る。この際の切除は, 粘膜層のみか, せいぜい声帯靶帯 までにとどめるため，術後の音声障害も軽微である。こ れで治痖率90\%前後が期待でき，この診断を兼ねた治療 法は，現在確立されたと言ってよい。

当科においては，声門癌 $\mathrm{T} 1$ 症例は，原則としてレー ザー手術を第一選択として治療を行ってきた。その治㾰 成績は，レーザー手術単独治獠例は57\%で，放射線照射 併用を含めた咽頭保存治癒例は89\%ですった。レーザー 手術単独治虞例が少ないのは，レーザー手術前期（1982 ～1986）に求いて，術後予防的に照射を併用した症例が
あったことと、レーザー手術が不十分であったことが原 因として考元ら机る。レーザー手術後期（1987～1991） では、T1症例の90\%がレーザー手術単独で治瘾してお り，照射併用の1例を含めると，20例（95\%）が咽頭を 保存して治蒸して㧍り，優扎た治療成績といえる。

レーザー手術後期においてレーザー手術単独での治痖 率が向上した理由上して，手術手技上以下のような点が 上げられる。すなわち，喉頭室方向の十分な切除が必要 なものでは，あらかじめ仮声带を切除してから腫瘍を切 除する。切除古るいは蒸散の深さについては，明らかに 表層のもの以外は，模様部では声带靱带あるいは声带筋 のレベルまで，前連合では甲状軟骨を露出するまで行う。 声帯後方の病紧に対しては挿管チューブを喉頭鏡先端で 前方に死排し術野をとる。照射方法としては蒸散を行わ ず，腫瘍は極力一塊として切除し，切除後に腫演の残存 が疑われる場合には蒸散を追加する、などである。

前連合の腫瘍をレーザーで制御できるかという点につ いては議諭のあるところで8)9310)，今回の対象症例に おいても，前連合部の腫湯に対するレーザー手術の結果 は１回の手術で制御された症例は $2 / 3$ 程度しかなく， またレーザー手術を繰り返しても制御できる率は少なく， 前連合に腫曒を認める T 1 b 症例はレーザー手術の適応 にならないという考え方もできる。ただし，今回の症例 のうち、レーザー手術後期の症例（６例）に限ると，前 連台の腫淣に対して甲状軟骨が一部露出するまで切除蒸 散を行ったことにより，5例(83\%) が1回のレーザー 手術で治痖し，残りの1例もレーザー手術の追加で治蒸 した。今後症例在重社て蚞討が必要ではあるが，現在で は前連合に腫濝が存在する症例も，甲状乾骨が露出する までレーザー照射を行うことにより，レーザー手術笚独 で制御可能と考えている。 
問題になるのは、治療後の音声機能であるが，T1症 例の放射線治療後とレーザ一治療㣪の音声在比較した報 告をみる上 机ている。レーザー手術例の音声障害の程度は多少出る 程度ですり，日常生活上の支障はない上付加されてはい るものの、レーザ一手術の短所といわざるをえない。今 回, 自験例の音声を検討した結果では, 最長発声持続時 間は正常より短く，低い声や小さい声が出しにくい傾向 があり，聴賞心理的評洒で83\%に㖽声を諗めた。こ㧈ら の障害の程度は、こ扎までに報告されたレーザー手術後 の音声障害と比べてより高度で高った。この理由として は、レーザー単独で治療することを目的としたため，従 来の報告例より，切除筙囲が広いものが多かったためと 思わ机る。ただ，音声障害が高度の症例においても，日 常生活上の支障はなく，恶性腫痬という疾患の特殊性を 考えると，ほぼ満足できる管声機能を保つことができた と考えている。

以上のことをま之めて考えると，声門部喉頭癌 T 1 症 例は，レーザー手術単独で90\%の治丞率が得られ，もし レーザー手術で腫痬が消失しなかった場合でも，放射線 治療を追加することにより，喉頭を保存して治丞せしめ ることができる(治療率は95\%)。術後の音声は，放射 線治療と比べて多少劣ってはいるものの，治療期間が短 い，咽喉頭炎に悩まされない，放射線誘発癌の心配がな いといった利点の臨床的意義は大きく，雳性腫源治療の

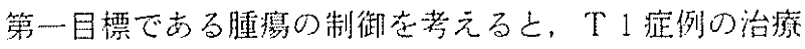
は、レーザー手術范第一拱択とする意味は十分にあると 考える。

\section{5. 結 論}

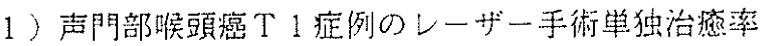
は約90\%である。もし、レーザー手術で腫湯が消失しな かった場合でも，放射線治療を追加することにより，喉 頭を保存して治痖せしめることができる。

2) 前連合に腫瘲が存在する症例も，甲状乾骨が露出 するまでレーザー照射を行うことに上り，レーザー手術 单独で制御可能と考元る。

3）レーザー治療後の音声は，最長発声持続時間は正 常より短く，低い声や小さい声が出しにくい傾向があり， 聴筧心理的評伍で83\%に嗄声在認めた。ただ，音声障害 が高瘦の症例においても、日常生活上の支障はなく，悪

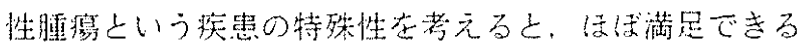
音声機能在保つことができたよ考える。

\section{文 献}

1) Strong MS and Jako GJ : Laser surgery in the larynx - clinical experience with continuous $\mathrm{CO}_{2}$ laser. Ann Otol Rhinol Laryngol 81 : 791 $798,1972$.

2 ) Inouye $\mathrm{T}$ : Application of $\mathrm{CO}_{2}$ laser to the carcinoma of the larynx.

Auris Nasus Larynx 12(Supp I. II) : 178 181, 1985.

3) Ossoff RH, Sisson GA and Shapshay SM : Endoscopic management of selected early vocal cord carcinoma. Ann Otol Rhinol Laryngol $94: 560 \sim 564,1985$.

4) 田部哲也，井上鐵三，小倉雅実他：声門部癌 $\mathrm{T} 1$, T 2 症例に対するレーザー治療と放射線治療の比較 検討，頭頝部腫㿉16（2）：103～108， 1990.

5 ）日本音声言語医学会編：声の検查法, 65〜 73頁, 187 ～191頁，214２40頁，医歯薬出版，東京， 1982

6 ) Blakeslee D, Vaughn CW, Shapshay SM et al: Excisional biopsy in the selective management of $\mathrm{T} 1$ glottic cancer: A three-year followup study. Laryngoscope $94:$ 488 494, 1984.

7) Koufman JA: The endoscopic management of early squamous carcinoma of the vocal cord with the carbon dioxide surgic al lase $r$ : Clinical experience and a proposed subclassifi cation. Otolaryngol Head and Neck Surg. 95 : $531 \sim 537,1986$.

8) Davis RK, Jako GJ, Hyams VJ et al: The anatomical limitations of $\mathrm{CO}_{2}$ laser cord ectomy. Laryngoscope 92 : 980 894, 1982.

9) Krespi YP and Meltzer CJ : Laser surgery for vocal cord carcinoma involving the anterior commissure. Ann Otol Rhinol Laryngol 98 : $105 \sim 109,1989$.

10）井上鐵三，田部哲也：前交連におよぶ声門癌のレー ザー手術. JOHNS 6 : 1383〜1386, 1990.

11) Hirano $M$, Hirade $Y$ and Kawasaki $H$ : Vocal function following carbon dioxide laser surgery for glottic carcinoma, Ann Otol Rhinol Laryngol $194: 232 \sim 235.1985$.

12）湯本英二，岡本和慧，河村裙二他：㬋頭癌治療にお けるレーザ一手術の応用之術後発声機能. 日耳粤 $88: 728 \sim 733,1985$

13)上垣克己: 声带に対するレーザー手術後の発声機能. 
耳鼻 $34: 837 \sim 858,1988$. 